\title{
Ethyl gallate suppresses proliferation and invasion in human breast cancer cells via Akt-NF-кB signaling
}

\author{
HONGXIA CUI ${ }^{1}$, JIAXIN YUAN ${ }^{1}$, XIAOHUI DU ${ }^{1}$, MING WANG $^{2}$, LILING YUE ${ }^{3}$ and JICHENG LIU $^{3}$ \\ ${ }^{1}$ Department of Clinical Pharmacology, Qiqihar Medical College, Qiqihar, Heilongjiang; ${ }^{2}$ Heilongjiang University of \\ Chinese Medicine, Harbin 150040; ${ }^{3}$ Institute of Medicine, Qiqihar Medical College, Qiqihar, Heilongjiang 161042, P.R. China
}

Received August 8, 2014; Accepted November 12, 2014

DOI: $10.3892 /$ or.2014.3682

\begin{abstract}
Euphorbia fischeriana Steud is a traditional Chinese Medicine that is known to possess a variety of anticarcinogenic properties. However, the bioactive constituents in Euphorbia fischeriana Steud and molecular mechanisms underlying this action in cancer treatment remain poorly understood. The present study investigated the chemotherapy activity and molecular targets of Ethyl gallate, which is identified as the major constituent extracted from the roots of Euphorbia fischeriana Steud in breast cancer cell lines in vitro. The results showed Ethyl gallate obviously decreased cell proliferation in MDA-MB-231 and MCF-7 cells in a dose- and time-dependent manner. Highly invasive MDA-MB231 cells were found to be highly sensitive to treatment. Furthermore, significantly decreased metastatic potential of highly metastatic MDA-MB-231 cells by Ethyl gallate was identified via the inhibition of cell motility using invasion and migration through a polyethylene terephthalate membrane. Ethyl gallate treatment decreased the activity of matrix metalloproteinase-2 (MMP-2) and MMP-9 by the downregulation of mRNA levels using RT-PCR, enzymes that are critical to tumor invasion. Treatment with Ethyl gallate decreased phosphatidylinositol 3-kinase (PI3K)/Akt and nuclear factor- $\kappa \mathrm{B}$ $(\mathrm{NF}-\kappa \mathrm{B})$ activation in MDA-MB-231 cells. These results indicate that Ethyl gallate suppresses proliferation and invasion in human breast cancer cells by modulating the PI3K/Akt pathway, which may contribute to inhibiting their downstream targets such as NF- $\kappa \mathrm{B}$ p- $65, \mathrm{Bcl}-2 / \mathrm{Bax}$, and mRNA levels of MMP-2 and MMP-9 in breast cancer cells. Thus, the present study shed new light on Ethyl gallate, an important bioactive constituent of Euphorbia fischeriana Steud, in human breast
\end{abstract}

Correspondence to: Dr Jicheng Liu, Institute of Medicine, Qiqihar Medical Univeristy, 333 Bukui Street, Jianhua, Qiqihar, Heilongjiang 161042, P.R. China

E-mail: xutianfang@sohu.com

Key words: Ethyl gallate, proliferation, invasion, MMP-9, Akt, NF-кB, human breast cancer cancer treatment. The findings may provide basal theories for wide therapeutic application in human breast cancer.

\section{Introduction}

Breast cancer cases (10-15\%) are characterized by an aggressive clinical with poor disease-free and overall survival and show a high rate of metastasis when compared with patients with other types of breast cancer (1-3). Currently, there is no defined standard antimetastasis treatment strategy for this disease other than traditional chemotherapy, to which it is highly resistant.

Tumor metastasis is a multistep process involving cell adhesion, cell migration and degradation of the extracellular matrix. The metastatic potential of tumor cells is influenced by a balance of the expression of proteases and their inhibitory proteins. Matrix metalloproteinases (MMPs) are a family of 24 secreted and membrane-type proteases that mediate this process. MMP-2 and MMP-9 are highly expressed in the breast and play an important role in the invasive stages of cancer (4).

The motility and invasive potential of a number of metastatic cancer cell lines has been inhibited by bioactive substances such as flavonoids (5), magnolol (6), tea catechins (7) and apigenin (8). Inhibition of MMP expression was also identified in a number of these studies.

The plant roots of Euphorbia fischeriana Steud, known as 'lang-du' in traditional Chinese medicine, have been used for the treatment of cancer for thousands of years (9-11). In recent years, studies have focused on Euphorbia fischeriana Steud, which has significant activity of inhibiting the growth of many tumors cell lines including leucocythemia K562, cervical carcinoma HeLa, nasopharyngeal carcinoma CNE2 and breast cancer. The bioactive substances in the roots of Euphorbia fischeriana Steud were concentrated on diterpenoids (12-15). The manner in which the bioactive constituent from Euphorbia fischeriana Steud exactly facilitates understanding of its involvement in cancer treatment remains to be determined. In the present study, five monomers from the roots of Euphorbia fischeriana Steud, and Ethyl gallate was identified as the major constituent. The aim of the study was to systematically analyze the potential activity of Ethy gallate on cancer cell lines and its molecular targets of action. Highly invasive MDA-MB-231 and low invasive MCF-7 human breast cell lines were employed, and treated with Ethyl gallate. Cell proliferation and apoptosis were 
analyzed, and the apoptotic-associated protein and expression of Bcl-2/Bax was assayed.

Highly invasive MDA-MB-231 cells were found to be highly sensitive to treatment. This observation led us to hypothesize whether the activity of Ethyl gallate extends to modulation of the metastatic potential as well. In the present study, the effect of Ethyl gallate against human highly invasive breast cancer, the abilities of cell adhesion, migration and invasion of as well as mRNA levels of MMP-2 and MMP-9 and PI3K/Akt and $\mathrm{NF}-\kappa \mathrm{B}$ signaling were evaluated. The results of the study provide important information on the role of Euphorbia fischeriana Steud as potential agents against the metastasis of breast cancer.

\section{Materials and methods}

Preparation of Ethyl gallate. Ethyl gallate (molecular weight of 198.1727 , purity $>99 \%$ ), which is light brown powder, was extracted by our laboratory and dissolved in phosphate-buffered saline (PBS) and diluted in a serials concentration. The chemical structure is as shown in Fig. 1A.

Cell lines and cell culture. Human breast cancer cell lines, estrogen receptor-negative MDA-MB-231 cells and estrogen receptor-positive MCF-7 cells were obtained from the Shanghai Cell Bank, Chinese Academy of Sciences (Shanghai, China). MDA-MB-231 cells were cultured in L15 medium $\left(\mathrm{Gibco}^{\mathrm{TM}}\right.$ Invitrogen Corporation, Carlsbad, CA, USA), while MCF-7 cells were cultured in DMEM medium with high glucose. Both medium were supplemented with $10 \%$ heat-inactived fetal bovine serum (FBS). The cells were cultured at $37^{\circ} \mathrm{C}$ in $5 \% \mathrm{CO}_{2}$ incubator and harvested by $0.25 \%$ trypsin.

Cell proliferation assay. The viability of breast cancer cells treated with Ethyl gallate was determined by 3-(4,5-dimethylthiazol-2-yl)-2,5-diphenyltetrazolium bromide (MTT) assay. Cells $\left(1.2 \times 10^{4}\right)$ /well in $200 \mu$ l full-cultured medium were seeded in 96 -well plates and incubated at $37^{\circ} \mathrm{C}$. After 24-h incubation, the medium was removed and replaced with full-cultured medium containing the final concentration of Ethyl gallate at $0,0.625,1.25,2.5,5,10,20,40$ and $80 \mu \mathrm{g} / \mathrm{ml}$. All groups were quadrupled. At 12, 24 and $48 \mathrm{~h}$ after treatment with Ethyl gallate, MTT solution was added to each well $\left(500 \mu \mathrm{g} / \mathrm{ml}\right.$ final concentrations) and incubated at $37^{\circ} \mathrm{C}$ for $4 \mathrm{~h}$. The supernatant was removed, and $150 \mu \mathrm{l}$ of dimethyl sulfoxide (DMSO) was added. The optical density value of the solution was read at $570 \mathrm{~nm}$ using a microplate reader (Safire2; Tecan Group Ltd., Maennedorf, Switzerland). The percentage of cell viability was determined by comparing the cell density of the drug-treated cells with that of untreated controls.

Analysis of apoptosis. MDA-MB-231 cells were treated with Ethyl gallate at a concentration of 0, 2.5, 5.0 and $10.0 \mu \mathrm{g} / \mathrm{ml}$ for $24 \mathrm{~h}$. Annexin $\mathrm{V}$ assays were carried out using the Annexin V-FITC apoptosis detection kit (Becton-Dickinson, San Jose, CA, USA). The treated cells were collected, washed in cold PBS, and then resuspended gently in $400 \mu \mathrm{l}$ of binding buffer prior to the addition of Annexin V-FITC and propidium iodide (PI). The cells were incubated for $15 \mathrm{~min}$ at room temperature, and 10,000 cells were analyzed for apoptosis using flow cytometry (BD Biosciences, San Jose, CA, USA). The percentage of apoptotic cells was quantified using CellQuest software (Becton-Dickinson). The experiments were repeated in triplicate separately.

Matrigel adhesion assay. The 96-well plates were precoated with $25 \mu \mathrm{g} /$ well of Matrigel (BD Biosciences). The MDA-MB231 cells $\left(1 \times 10^{5} /\right.$ well $)$ were incubated in $1 \mathrm{ml}$ of serum-free medium containing Ethyl gallate at concentrations of 0, 2.5, 5.0 and $10.0 \mu \mathrm{g} / \mathrm{ml}$ and labeled by derivatives of indocarbocyanine iodide (DiI; $3 \mu \mathrm{g} / \mathrm{ml}$ ) for $2 \mathrm{~h}$ at $37^{\circ} \mathrm{C}$, respectively. Then cells were washed twice with PBS and seeded into the precoated wells and incubated for $30 \mathrm{~min}$ at $37^{\circ} \mathrm{C}$ in a $5 \% \mathrm{CO}_{2}$ incubator. The cells were washed twice with PBS gently to remove unadhered cells, and the number of cells adhered to the Matrigel was counted in five randomly selected microscopic fields per well and photographed by fluorescence microscope. Independent experiments were performed at least three times.

In vitro migration and invasion assay. Tumor cell migration and invasion were examined using Transwell chambers (Costar, Corning, Inc., Corning, NY, USA). Briefly, Matrigel was coated the upper chamber for invasion (not for migration). MDA-MB-231 cells $\left(5 \times 10^{4}\right.$ for invasion and $2 \times 10^{5}$ for migration) were incubated in $1 \mathrm{ml}$ of serum-free medium containing Ethyl gallate at concentrations of $0,2.5,5.0$ and $10.0 \mu \mathrm{g} / \mathrm{ml}$ for $2 \mathrm{~h}$, respectively, washed in PBS and seeded in the upper chamber in $200 \mu \mathrm{l}$ of serum-free medium, while the lower chamber was filled with $600 \mu \mathrm{l}$ of medium supplemented with $10 \%$ of FBS. After 24 -h incubation at $37^{\circ} \mathrm{C}$, the cells on the upper chambers were scraped with a cotton swab. Cells migrating or invading to the lower surface were fixed with methanol for $30 \mathrm{~min}$, stained with $0.1 \%$ crystal violet for $20 \mathrm{~min}$, washed with PBS, photographed with fluorescence microscope and incorporated dye was dissolved in $10 \%$ acetic acid. The optical densities of each well were measured using a microplate reader at $570 \mathrm{~nm}$. Experiments were repeated three times.

Protein extraction and western blot analysis. Cells were treated as described for the apoptosis assay. Total cellular proteins were extracted. Equivalent amounts of cellular protein were electrophoresed in 10\% SDS-PAGE gel and transfered to nitrocellullose membranes (Millipore, Billerica, MA, USA) and blocked in 5\% non-fat milk in TBST for $1 \mathrm{~h}$ at room temperature. The cells were incubated with primary antibodies to human Bcl-2 and Bax (both from Santa Cruz Biotechnology, Inc., Santa Cruz, CA, USA), NF-кB p-65, Akt and p-Akt (Cell Signal Technology, Inc., Danvers, MA, USA) and GAPDH in $5 \%$ non-fat milk at $4^{\circ} \mathrm{C}$ overnight. The membranes were washed with TBST and incubated with horseradish peroxidase-conjugated secondary antibody in 5\% non-fat milk for $1 \mathrm{~h}$ at room temperature. Immune complexes were detected by enhanced chemoluminescence techniques (Amersham Life Science, Piscataway, NJ, USA). Band densities were quantified by using BandScan software.

Semi-quantitative reverse transcription-PCR. Total cellular RNA was extracted using TRIzol reagent (Invitrogen) and quantified by spectrophotometry. RT-PCR reaction was carried out using an RT-PCR kit (Takara Biotechnology, 
A<smiles>CCOC(=O)c1cc(O)c(O)c(O)c1</smiles>

C

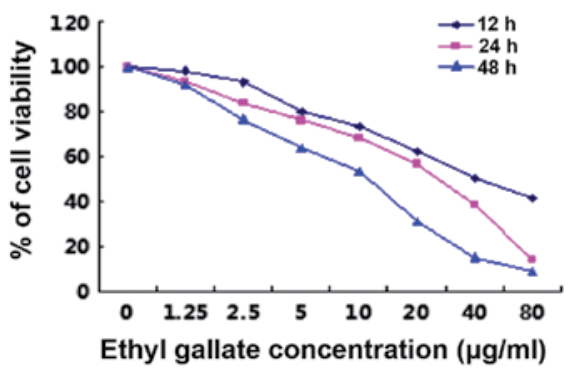

B

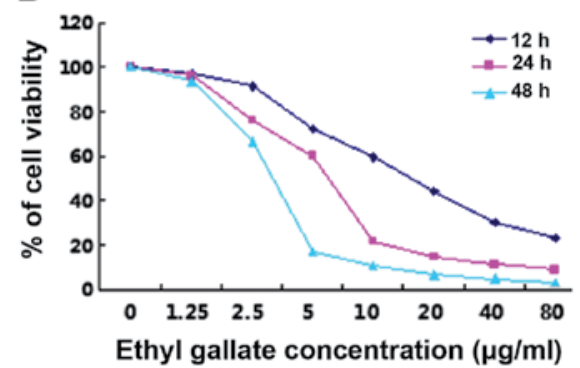

D

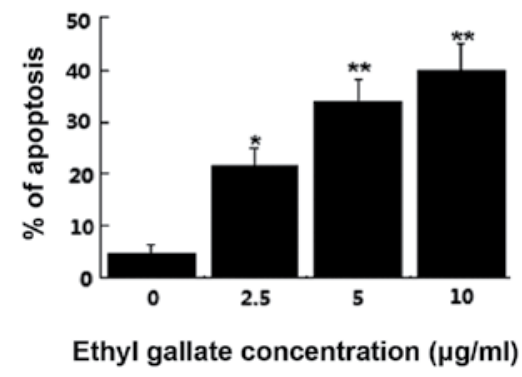

Figure 1. Ethyl gallate inhibition of cell proliferation and induction apoptosis. (A) Chemical structure of Ethyl gallate $\left(\mathrm{C}_{9} \mathrm{H}_{10} \mathrm{O}_{5}, \mathrm{Mr}\right.$ 198.1727), (B and C) MDA-MB-231 and MCF-7 cells were treated with an increasing concentration of Ethyl gallate for 12, 24 and 48 h. Cell viability was determined using MTT assay. Data are expressed as a ratio of treated samples to untreated controls $(0 \mu \mathrm{g} / \mathrm{ml}$ as untreated control). (D) MDA-MB-231 cells were exposed to Ethyl gallate at indicated concentrations for $24 \mathrm{~h}$, collected, and cell apoptosis was measured by Annexin V-FITC and PI. The bar chart describes the percentage of apoptosis obtained from three separate experiments and are presented as means $\pm \mathrm{SD}$. ${ }^{*} \mathrm{P}<0.05$ and ${ }^{* *} \mathrm{P}<0.01$ compared to 0 as untreated control.

Dalian, China) according to the manufacturer's instructions. PCR amplification was carried out with the following primers: MMP-2, forward: 5'-GGATGATGCCTTTGCTCG-3' and reverse: 5'-CAGTGGACATGGCGGTCT-3'; MMP-9, forward: 5'-TCCCTGGAGACCTGAGAACC-3' and reverse: 5'-GGC AAGTCTTCCGAGTAGTTT-3'; $\beta$-actin, forward: 5'-ATCATG TTTGAGACCTTCAACACC-3' and reverse: 5'-TAGCTCTTC TCCAGGGAGG-3'. The amplification products were separated through a $1.5 \%$ agarose gel electrophoresis. The intensity of each band was quantified using Scion Image software (Scion Corporation, Frederick, MD, USA). Results for each detected band intensity were normalized to $\beta$-actin band intensity values.

Statistical analysis. Values were expressed as means \pm standard deviation and analyzed by the SPSS 13.0 software to evaluate the statistical difference. One-way analysis of variance (ANOVA) was used to establish whether significant differences existed among multiple groups. $\mathrm{P}<0.05$ was considered to indicate a statistically significant result.

\section{Results}

Ethyl gallate inhibits proliferation and induces apoptosis of breast cancer cells in a dose-and time-dependent manner. The effects of Ethyl gallate on the proliferation of MDA-MB231 [estrogen receptor-negative (ER $)$ ] and MCF-7 [estrogen receptor-positive $\left.\left(\mathrm{ER}^{+}\right)\right]$human breast cancer cell lines were investigated using an MTT assay. The same amount of cells was seeded and treated with a series of concentrations of Ethyl gallate from 0 to $80 \mu \mathrm{g} / \mathrm{ml}$. The results showed that Ethyl gallate significantly inhibited cell proliferation in the MDA-MB-231 and MCF-7 cells in a dose- and time-depen- dent manner following treatment for 12,24 and $48 \mathrm{~h}$. The $\mathrm{IC}_{50}$ values at 12,24 and $48 \mathrm{~h}$ were $17.85,6.55$ and $2.95 \mu \mathrm{g} / \mathrm{ml}$ and 32.53, 16.88 and $9.40 \mu \mathrm{g} / \mathrm{ml}$ for MDA-MB-231 (Fig. 1B) MCF-7 (Fig. 1C) cells, respectively. However, MDA-MB-231 cells $\left(\mathrm{ER}^{-}\right)$were more sensitive to Ethyl gallate than MCF-7 cells $\left(\mathrm{ER}^{+}\right)$.

To determine whether the decreased cell numbers occurred due to the induction of cell death, apoptosis was quantitatively analyzed by flow cytometry. Following treatment with Ethyl gallate at concentrations of $2.5,5.0$ and $10.0 \mu \mathrm{g} / \mathrm{ml}$ for $24 \mathrm{~h}$ in the MDA-MB-231 cells, the percentage of apoptosis was $21.50,33.86$ and $39.77 \%$, respectively (Fig. 1D). The results suggested that apoptosis is an important mechanism of Ethyl gallate in the induction of breast cancer cell death.

Effect of Ethyl gallate on Bcl-2 and Bax proteins involved in apoptosis. Pro-apoptotic molecular mechanisms underlying Ethyl gallate were examined. We investigated the expression of Bcl-2 and Bax, which are pivotal regulators of cell growth and apoptosis. Western blot analysis revealed that Ethyl gallate decreased Bcl-2 but increased Bax in a dose-dependent manner (Fig. 2). Thus, Ethyl gallate may induce apoptosis by altering the $\mathrm{Bax} / \mathrm{Bcl}-2$ ratio favoring apoptosis.

Ethyl gallate reduces cell adhesion, migration and invasion. Considering that highly invasive breast cancer cells were more sensitive to treatment with Ethyl gallate than poorly invasive ones, we determined whether Ethyl gallate inhibited the invasive behavior of breast cancer cells. Tumor invasion involve cell adhesion to the extracellular matrix, migration and invasion to Matrigel. To investigate the effect of Ethyl gallate on breast cancer invasion potential, cell adhesion, migration and invasion assays were examined in highly invasive MDA-MB-231 
A

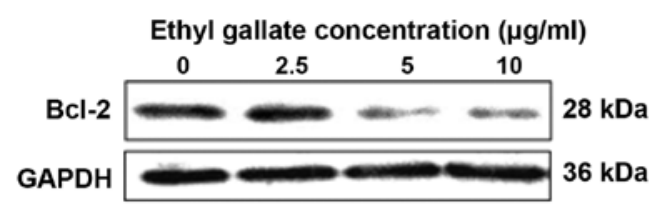

B

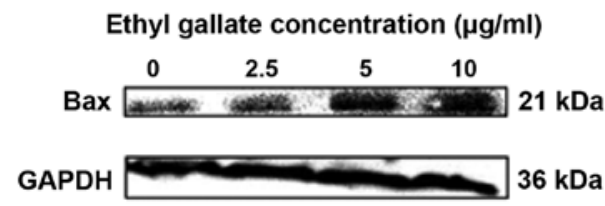

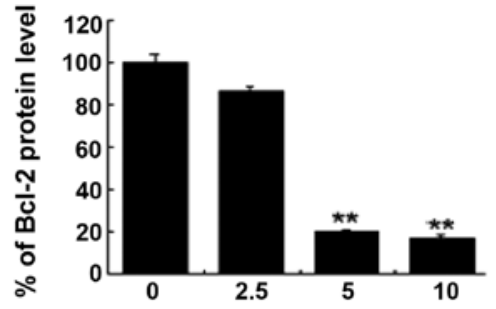

Ethyl gallate concentration $(\mu \mathrm{g} / \mathrm{ml})$

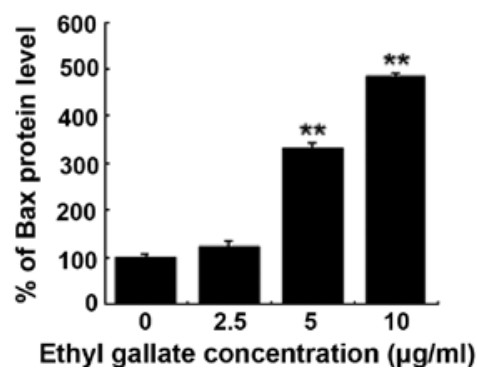

Figure 2. Ethyl gallate regulated the expression of Bcl-2 and Bax. (A and B) Representative image of western blotting of cell proteins of MDA-MB-231-treated for $24 \mathrm{~h}$ at the indicated concentrations. Band density (normalized to GAPDH), shown as means \pm SD, is relative to that of 0 as the control (designated as $100 \%$ ). Comparison was conducted by one-way ANOVA. ${ }^{* *} \mathrm{P}<0.01$ compared to the control.
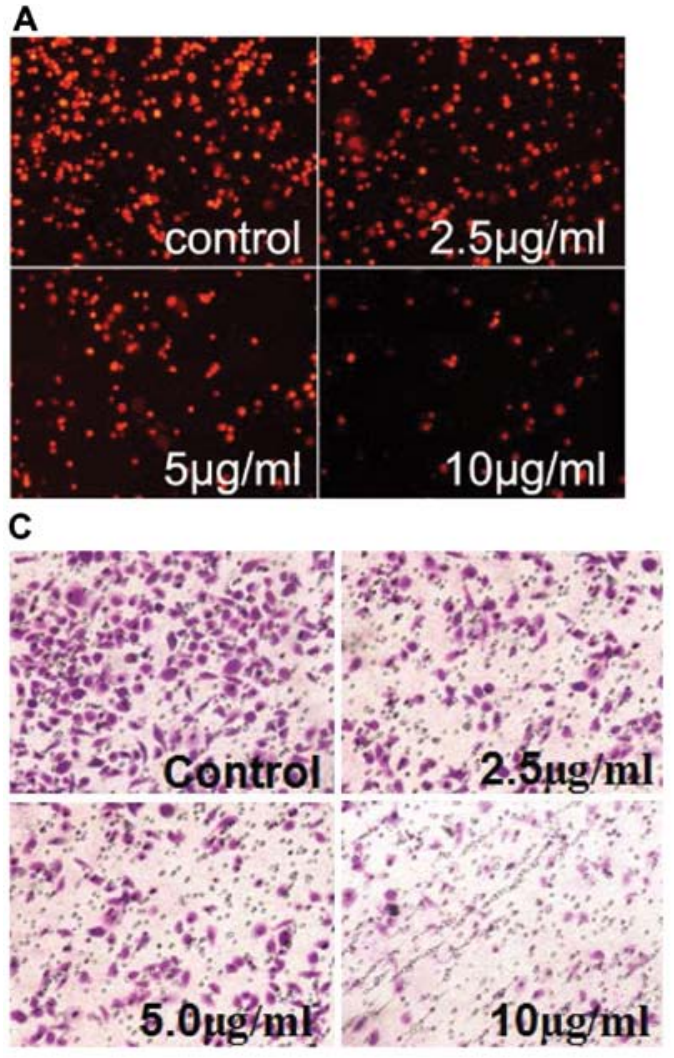

B

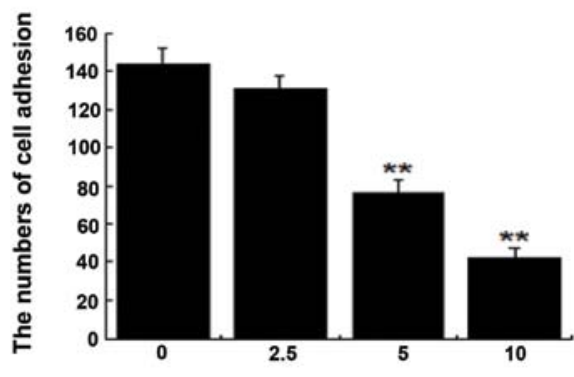

Ethyl gallate concentration $(\mu \mathrm{g} / \mathrm{ml})$

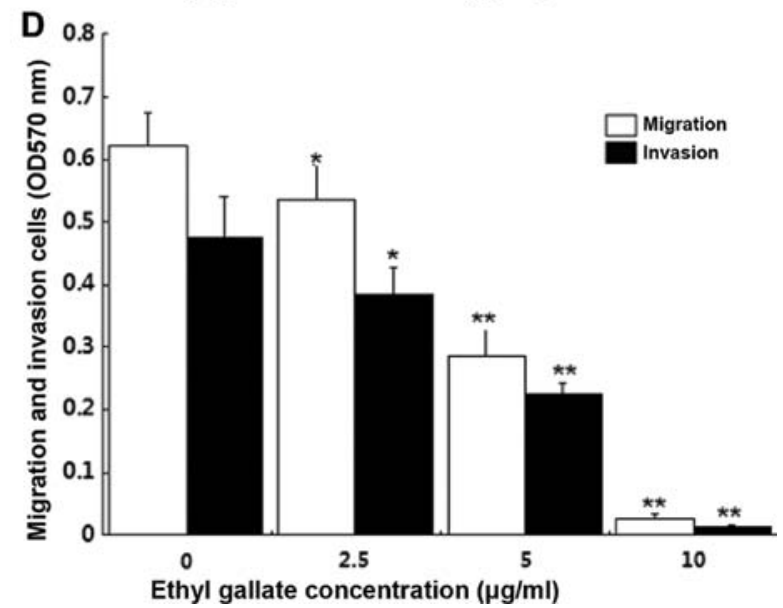

Figure 3. Ethyl gallate reduced cell adhesion, migration and invasion. (A) Images indicate the Dil-stained MDA-MB-231 cells that adhered to Matrigel were treated with Ethyl gallate for $2 \mathrm{~h}$ at indicated concentration. (B) Number of adhering cells were counted by fluorescence microscope and were shown as means \pm SD. (C) Images indicate the crystal violet-stained MDA-MB-231 cells migrating through the Transwell chamber. The cells were treated for $2 \mathrm{~h}$ with 0 (as control) and $10 \mu \mathrm{g} / \mathrm{ml}$. (D) Optical densities of migration and invasion were read at $570 \mathrm{~nm}$ and were shown as means \pm SD. Statistical analysis was carried out using ANOVA. ${ }^{*} \mathrm{P}<0.05,{ }^{* *} \mathrm{P}<0.01$ compared to the control.

cells. As shown, the number of cells that adhered to Matrigel was $143.78 \pm 8.53,121.38 \pm 6.38,76.34 \pm 6.32$ and $42.0 \pm 5.18$, respectively (Fig. 3A). Twenty-four hours after cell migration and invasion, the optical density of MDA-MB-231 cells were $0.623 \pm 0.053,0.476 \pm 0.064,0.536 \pm 0.059,0.385 \pm 0.043$, $0.284 \pm 0.048,0.225 \pm 0.016,0.027 \pm 0.006$ and $0.014 \pm 0.002$ respectively, following cell treatment with Ethyl gallate at concentrations of 2.5, 5.0 and $10.0 \mu \mathrm{g} / \mathrm{ml}$ for $2 \mathrm{~h}$ (Fig. 3B). 

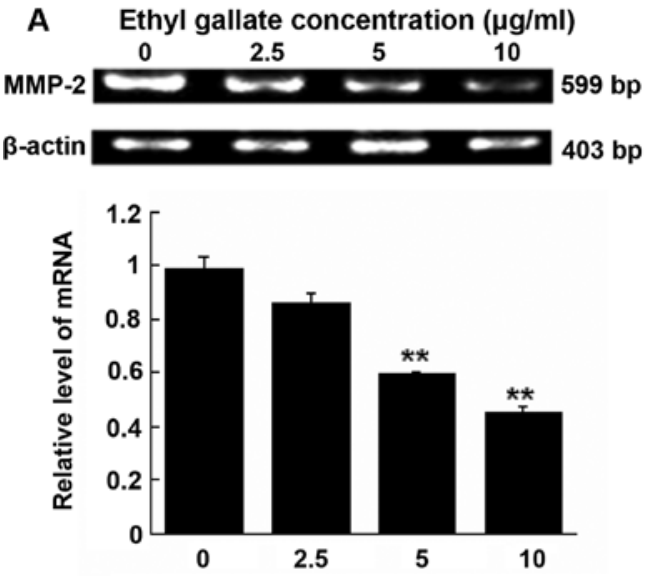

Ethyl gallate concentration $(\mu \mathrm{g} / \mathrm{ml})$
B Ethyl gallate concentration $(\mu \mathrm{g} / \mathrm{ml})$
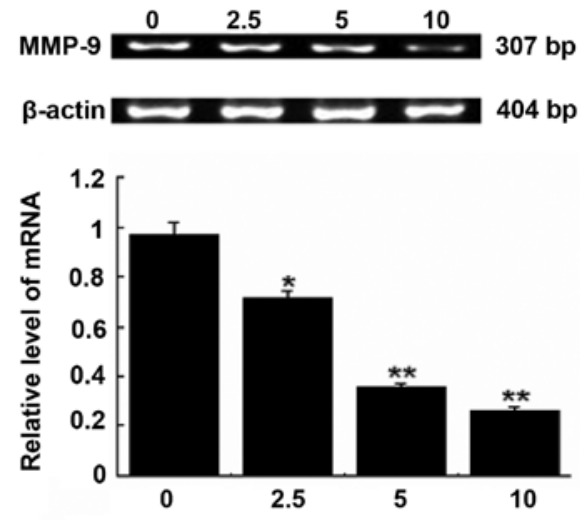

Ethyl gallate concentration $(\mu \mathrm{g} / \mathrm{ml})$

Figure 4. Ethyl gallate suppressed mRNA expression of (A) MMP-2 and (B) MMP-9. The mRNA expression was determined by semi-quantitative RT-PCR following cell treatment for $24 \mathrm{~h}$ with Ethyl gallate at the indicated concentration. mRNA expressions levels were normalized to $\beta$-actin. Band densities (normalized to $\beta$-actin) were shown as means $\pm \mathrm{SD}$, relative to that of 0 (as the control, designated as 1.0). Statistical analysis was carried out using the ANOVA ${ }^{*} \mathrm{P}<0.05$ and $^{* *} \mathrm{P}<0.01$ compared to the control.

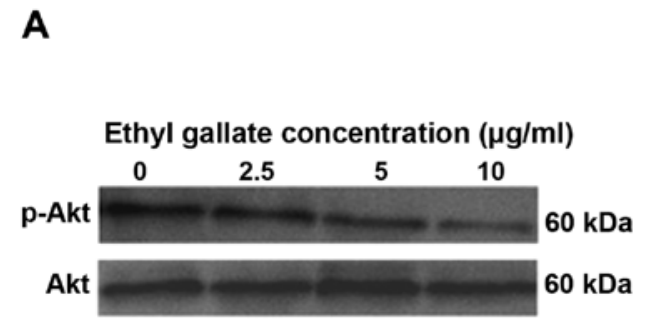

B

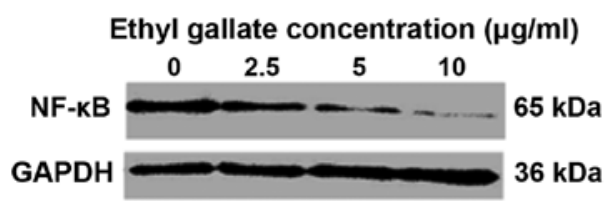

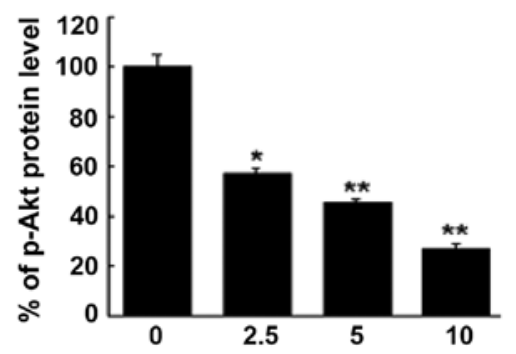

Ethyl gallate concentration $(\mu \mathrm{g} / \mathrm{ml})$

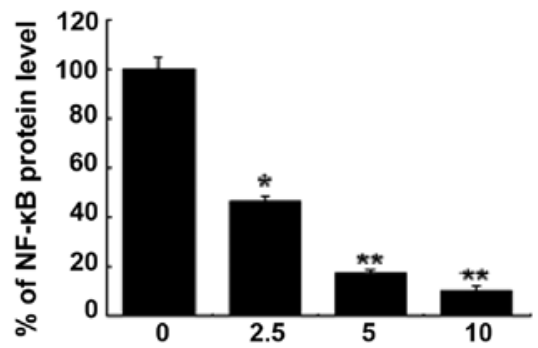

Ethyl gallate concentration $(\mu \mathrm{g} / \mathrm{ml})$

Figure 5. Ethyl gallate inhibited the activity of Akt and NF- $\mathrm{kB}$ in MDA-MB-231 cells. (A and B) Akt and NF- $\mathrm{B}$ in cell lysates from cells treated with Ethyl gallate were determined via western blotting and chemiluminescence. The density of the p-Akt band (normalized to Akt) and the density of the NF- $\mathrm{kB}$ band (normalized to GAPDH) were shown as means \pm SD is relative to that of 0 (as the control, designated as $100 \%$ ). Statistical analysis was carried out using the ANOVA. ${ }^{*} \mathrm{P}<0.05$ and ${ }^{* *} \mathrm{P}<0.01$ compared to the control.

The results suggested that Ethyl gallate at short effect time significantly suppressed the adhesion, migration and invasion of MDA-MB-231 cells with the inhibition rate of 13.40, 13.89, $19.12,46.90,54.42,52.74 \%$, and 70.79, 95.67, 97.06\% (Fig. 3C).

Inhibition of MMP-2 and MMP-9 expression by Ethyl gallate. Degradation of the extracellular matrix relative proteins, MMP-2 and MMP-9 is important in the invasive stages of cancer. RT-PCR detection demonstrated that Ethyl gallate at 5.0 and $10.0 \mu \mathrm{g} / \mathrm{ml}$ significantly reduced the mRNA levels of $M M P$-2 (Fig. 4A) and MMP-9 (Fig. 4B) in MDA-MB-231 cells following cell treatment for $24 \mathrm{~h}$ with Ethyl gallate.
Inhibition of cell signaling pathway by Ethyl gallate. The importance of the PI3K/Akt and NF- $\mathrm{KB}$ signaling pathways to tumor cell growth and invasion was investigated. $\mathrm{NF}-\kappa \mathrm{B}$ is a critical transcription factor involved in the regulation of MMP-9 expression. To further understand the inhibitory mechanisms of Ethyl gallate on $M M P-9$ transcriptional regulation, the $\mathrm{PI} 3 \mathrm{~K} / \mathrm{Akt}$ and $\mathrm{NF}-\kappa \mathrm{B}$ signaling pathways were investigated by western blot analysis. The results revealed that Ethyl gallate significantly reduced Akt phosphorylation at 5.0 and $10.0 \mu \mathrm{g} / \mathrm{ml}(\mathrm{P}<0.05$ and $0.01 ;$ Fig. $5 \mathrm{~A})$, and also decreased the activity of $\mathrm{NF}-\kappa \mathrm{B}$ at $5.0 \mu \mathrm{g} / \mathrm{ml}(\mathrm{P}<0.05)$ and $10.0 \mu \mathrm{g} / \mathrm{ml}$ $(\mathrm{P}<0.01$; Fig. 5B). By contrast, the inhibition of PI3K/Akt 
leading to downregulation of NF- $\mathrm{KB}$ activation may be one mechanism of Ethyl gallate against MDA-MB-231 cell proliferation and invasion.

\section{Discussion}

Euphorbia fischeriana Steud is known to inhibit tumor cell growth. The bioactive constituents from the roots of Euphorbia fischeriana Steud were concentrated on diterpenoids. However, in the present study, we found that Ethyl gallate, which is identified as the major constituent in Euphorbia fischeriana Steud extracts, potently inhibits proliferation and induces apoptosis of breast cancer cells in dose- and time-dependent manners in vitro. MDA-MB-231 cells (ER-) were more sensitive to Ethyl gallate than MCF-7 cells $\left(\mathrm{ER}^{+}\right)$(Fig. 1). This result shows that Ethyl gallate is an important bioactive constituent in the chemotherapy of breast cancer through the pathways of marked induction of cell apoptosis. Induction of apoptosis was primarily due to altering $\mathrm{Bax} / \mathrm{Bcl}-2$ ratio (Fig. 2), providing evidence for understanding the manner in which Euphorbia fischeriana Steud functions in cancer treatment.

Metastasis is the main cause of mortality in cancer patients (16). During the complicated processes of metastasis, the adhesion to the extracellular matrix (ECM), migration and invasion of cancer cells are the most pivotal steps for motility to distant sites. Many bioactive substances have been proven to inhibit an invasive potential of metastatic cancer cell lines, including prostate, lung and breast (17-19). In the present study, we have shown that Ethyl gallate markedly inhibited cell adhesion in Matrigel (Fig. 3) and the migratory abilities of highly invasive MDA-MB-231 breast cells. The anti-invasive capacity of Ethyl gallate may be important in decreasing mortality and improving the survival time in ER breast cancer patients.

For tumor invasion, matrix metalloproteinases (MMPs) are the best documented critical proteolytic enzymes associated with degradation of ECM (20-22). It is believed that this characteristic initiates the metastatic process and enables tumor cells to invade and spread to various secondary sites. To facilitate metastasis, tumor cells depend on the activity of more than one MMP, enabling them to cross the tissue barriers they encounter during the process of invasion. Although many MMPs have been identified, MMP-2 (gelatinase A) and MMP-9 (gelatinase B) are the enzymes most pivotal to degrading ECM $(23,24)$, and they are highly expressed in highly metastatic tumors (25). MMP activity is regulated by gene transcription, while its expression level is directly associated with invasion and metastasis of tumor. Thus, MMP-2 and MMP-9 are considered to be a target for breast cancer therapy by suppressing breast cancer invasion (26). The present study demonstrated that Ethyl gallate treatment significantly inhibited the activity of $M M P-2$ and $M M P-9$ by downregulating mRNA expression levels in MDA-MB-231 cells compared with the untreated control (Fig. 4). Therefore, MMP-2 and MMP-9 may be Ethyl gallate-responsive mediators whose degradation of ECM may cause subsequent cancer migration and invasion.

In addition, the efficacy of Ethyl gallate can be explained by interference with the PI3K/Akt and NF- $\mathrm{KB}$ signaling pathways, which have been found to be important in growth, invasion and metastasis of tumor cells (27). It has been shown that the NF- $\kappa B$ signal a major pathway for modulating MMP-9 expression $(28,29)$. In the present study, Akt phosphorylation and NF- $\mathrm{KB}$ activation were found to be inhibited by Ethyl gallate treatment, although there was no effect on total Akt (Fig. 5). $\mathrm{NF}-\mathrm{\kappa B}$ is a nuclear transcription regulator for Bcl-2 transcription $(30,31)$. The Bcl-2, Bax, p-Akt and NF- $\mathrm{KB}$ have become the main targets of action by anticancer agents (32-34). Ethyl gallate inhibits the PI3K/Akt and NF- $\mathrm{KB} / \mathrm{Bcl}-2$ signaling pathways by suppressing the phosphorylation of Akt and NF- $\kappa B$ expression in MDA-MB-231 cells. This inhibition may contribute to downregulation of the Bcl-2/Bax ratio and mRNA expression levels of $M M P-2$ and $M M P-9$ in human breast cancer cells. These data provide a basic mechanism for Ethyl gallate chemotherapeutic properties of human breast cancer cells.

Abnormal growth and metastasis are considered as important biological properties of cancer cells. An agent that efficiently inhibited these biological properties of cancer cells is a potential candidate for the suppression of cancer progression. Our data suggest that Ethyl gallate is an effective agent to target breast cancer proliferation as well as migration and invasion. These inhibitory effects are at least partially mediated by interference with the Akt-NF- $\kappa \mathrm{B}$ signaling pathway.

Future studies are required to analyze the precise mechanism(s) of Ethyl gallate and to exploit its full potential for breast cancer chemotherapy. In vivo studies are pivotal to confirm these in vitro mechanisms and determine future therapeutic applications of Ethyl gallate against breast cancer.

\section{Acknowledgements}

This study was supported by the National Natural Science Foundation of China (no. 81374021), and the Youth Leading Scholar Supporting Program in General Colleges and Universities of Heilongjiang, China (no. 1253G067).

\section{References}

1. Cleator S, Heller W and Coombes RC: Triple-negative breast cancer: therapeutic options. Lancet Oncol 8: 235-244, 2007.

2. van de Rijn M, Perou CM, Tibshirani R, et al: Expression of cytokeratins 17 and 5 identifies a group of breast carcinomas with poor clinical outcome. Am J Pathol 161: 1991-1996, 2002.

3. Foulkes WD, Brunet JS, Stefansson IM, et al: The prognostic implication of the basal-like (cyclin $\mathrm{E}^{\text {high }} / \mathrm{p} 27^{\text {low }} / \mathrm{p} 53^{+} / \mathrm{glomeru}-$ loid-microvascular-proliferation ${ }^{+}$) phenotype of $B R C A 1$-related breast cancer. Cancer Res 64: 830-835, 2004.

4. Folgueras AR, Pendás AM, Sánchez LM and López-Otín C: Matrix metalloproteinases in cancer: from new functions to improved inhibition strategies. Int J Dev Biol 48: 411-424, 2004.

5. Lin YC, Tsai PH, Lin CY, Cheng $\mathrm{CH}$, Lin $\mathrm{TH}$, Lee KP, Huang KY, Chen SH, Hwang JJ, Kandaswami CC and Lee MT: Impact of flavonoids on matrix metalloproteinase secretion and invadopodia formation in highly invasive A431-III cancer cells. PLoS One 8: e71903, 2013.

6. Liu Y, Cao W, Zhang B, Liu YQ, Wang ZY, Wu YP, Yu XJ, Zhang XD, Ming PH, Zhou GB and Huang L: The natural compound magnolol inhibits invasion and exhibits potential in human breast cancer therapy. Sci Rep 3: 3098, 2013.

7. Ho YC, Yang SF, Peng CY, Chou MY and Chang YC: Epigallocatechin-3-gallate inhibits the invasion of human oral cancer cells and decreases the productions of matrix metalloproteinases and urokinase-plasminogen activator. J Oral Pathol Med 36: 588-593, 2007. 
8. Lee WJ, Chen WK, Wang CJ, Lin WL and Tseng TH: Apigenin inhibits HGF-promoted invasive growth and metastasis involving blocking PI3K/Akt pathway and $\beta 4$ integrin function in MDA-MB-231 breast cancer cells. Toxicol Appl Pharmacol 226: 178-191, 2008

9. Qin GW and Xu RS: Recent advances on bioactive natural products from Chinese medicinal plants. Med Res Rev 18: 375-382, 1998

10. Wang YB, Huang R, Wang HB, Jin HZ, Lou LG and Qin GW: Diterpenoids from the roots of Euphorbia fischeriana. J Nat Prod 69: 967-970, 2006.

11. Shi HM, Williams ID, Sung HH, Zhu HX, Ip NY and Min ZD: Cytotoxic diterpenoids from the roots of Euphorbia ebracteolata. Planta Med 71: 349-354, 2005.

12. Wang JH, Zhang K, Niu HY, Shu LH, Yue DM, Li D and He P: Jolkinolide B from Euphorbia fischeriana Steud induces in human leukemic cells apoptosis via JAK2/STAT3 pathways. Int J Clin Pharmacol Ther 51: 170-178, 2013.

13. Yan SS, Li Y, Wang Y, Shen SS, Gu Y, Wang HB, Qin GW and Yu Q: 17- Acetoxyjolkinolide B irreversibly inhibits IкB kinase and induces apoptosis of tumor cells. Mol Cancer Ther 7: 1523-1532, 2008.

14. Wang JH, Zhou YJ, Bai X and He P: Jolkinolide B from Euphorbia fischeriana Steud induces apoptosis in human leukemic U937 cells through PI3K/Akt and XIAP pathways. Mol Cells 32: 451-457, 2011.

15. Wang Y, Ma X, Yan S, Shen S, Zhu H, Gu Y, Wang H, Qin G and Yu Q: 17-Hydroxy-jolkinolide B inhibits signal transducers and activators of transcription 3 signaling by covalently crosslinking Janus kinases and induces apoptosis of human cancer cells. Cancer Res 69: 7302-7310, 2009.

16. Chaffer CL and Weinberg RA: A perspective on cancer cell metastasis. Science 331: 1559-1564, 2011.

17. Hung SH, Shen KH, Wu CH, Liu CL and Shih YW: $\alpha$-Mangostin suppresses PC-3 human prostate carcinoma cell metastasis by inhibiting matrix metalloproteinase-2/9 and urokinase-plasminogen expression through the JNK signaling pathway. J Agric Food Chem 57: 1291-1298, 2009.

18. Chen PN, Chu SC, Chiou HL, Kuo WH, Chiang CL and Hsieh YS: Mulberry anthocyanins, cyanidin 3-rutinoside and cyanidin 3-glucoside, exhibited an inhibitory effect on the migration and invasion of a human lung cancer cell line. Cancer Lett 235: 248-259, 2006.

19. Azios NG and Dharmawardhane SF: Resveratrol and estradiol exert disparate effects on cell migration, cell surface actin structures, and focal adhesion assembly in MDA-MB-231 human breast cancer cells. Neoplasia 7: 128-140, 2005.

20. Kessenbrock K, Plaks V and Werb Z: Matrix metalloproteinases: regulators of the tumor microenvironment. Cell 141: 52-67, 2010.

21. Das R, Philip S, Mahabeleshwar GH, Bulbule A and Kundu GC: Osteopontin: it's role in regulation of cell motility and nuclear factor $\kappa \mathrm{B}$-mediated urokinase type plasminogen activator expression. IUBMB Life 57: 441-447, 2005.
22. Lu KW, Tsai ML, Chen JC, Hsu SC, Hsia TC, Lin MW, Huang AC, Chang YH, Ip SW, Lu HF and Chung JG: Gypenosides inhibited invasion and migration of human tongue cancer SCC4 cells through down-regulation of NFKB and matrix metalloproteinase-9. Anticancer Res 28: 1093-1099, 2008.

23. Park SY, Kim JH, Lee YJ, Lee SJ and Kim Y: Surfactin suppresses TPA-induced breast cancer cell invasion through the inhibition of MMP-9 expression. Int J Oncol 42: 287-296, 2013.

24. Hojilla CV, Mohammed FF and Khokha R: Matrix metalloproteinases and their tissue inhibitors direct cell fate during cancer development. Br J Cancer 89: 1817-1821, 2003.

25. Kim Y, Kang H, Jang SW and Ko J: Celastrol inhibits breast cancer cell invasion via suppression of NF-KB-mediated matrix metalloproteinase-9 expression. Cell Physiol Biochem 28: 175-184, 2011.

26. Rangaswami H, Bulbule A and Kundu GC: Nuclear factorinducing kinase plays a crucial role in osteopontin-induced MAPK/I $\kappa \mathrm{B} \alpha$ kinase-dependent nuclear factor $\kappa \mathrm{B}$-mediated promatrix metalloproteinase-9 activation. J Biol Chem 279: 38921-38935, 2004.

27. Yamaguchi N, Ito T, Azuma S, Ito E, Honma R, Yanagisawa $\mathrm{Y}$, Nishikawa A, Kawamura M, Imai J, Watanabe S, Semba K and Inoue J: Constitutive activation of nuclear factor- $\kappa \mathrm{B}$ is preferentially involved in the proliferation of basal-like subtype breast cancer cell lines. Cancer Sci 100: 1668-1674, 2009.

28. Kang H, Lee M, Choi KC, Shin DM, Ko J and Jang SW: $N-(4-$ hydroxyphenyl)retinamide inhibits breast cancer cell invasion through suppressing NF-KB activation and inhibiting matrix metalloproteinase-9 expression. J Cell Biochem 113: 2845-2855, 2012.

29. Thangapazham RL, Passi N and Maheshwari RK: Green tea polyphenol and epigallocatechin gallate induce apoptosis and inhibit invasion in human breast cancer cells. Cancer Biol Ther 6 : 1938-1943, 2007.

30. Viatour P, Bentires-Alj M, Chariot A, Deregowski V, de Leval L, Merville MP and Bours V: NF- $\mathrm{BB} 2 / \mathrm{p} 100$ induces Bcl-2 expression. Leukemia 17: 1349-1356, 2003.

31. Marsden VS, O'Connor L, O'Reilly LA, Silke J, Metcalf D, Ekert PG, Huang DC, Cecconi F, Kuida K, Tomaselli KJ, Roy S, Nicholson DW, Vaux DL, Bouillet P, Adams JM and Strasser A: Apoptosis initiated by $\mathrm{Bcl}-2$-regulated caspase activation independently of the cytochrome c/Apaf-1/caspase-9 apoptosome. Nature 419: 634-637, 2002.

32. Emi M, Kim R, Tanabe K, Uchida Y and Toge T: Targeted therapy against Bcl-2-related proteins in breast cancer cells. Breast Cancer Res 7: 940-952, 2005.

33. Patel JB, Mehta J, Belosay A, Sabnis G, Khandelwal A, Brodie AM, Soprano DR and Njar VC: Novel retinoic acid metabolism blocking agents have potent inhibitory activities on human breast cancer cells and tumour growth. Br J Cancer 96: 1204-1215, 2007.

34. Aggarwal BB: Nuclear factor- $\kappa$ B: the enemy within. Cancer Cell 6: 203-208, 2004. 